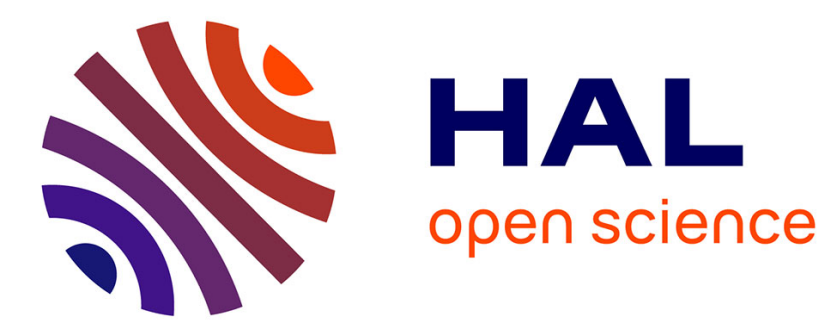

\title{
Proteolysis of type III collagen by collagenase and cathepsin B under high hydrostatic pressure
}

\author{
E. Dufour, Michèle Dalgalarrondo, Guillaume Hervé, R. Goutefongea, Thomas
}

Haertlé

\section{- To cite this version:}

E. Dufour, Michèle Dalgalarrondo, Guillaume Hervé, R. Goutefongea, Thomas Haertlé. Proteolysis of type III collagen by collagenase and cathepsin B under high hydrostatic pressure. Meat Science, 1996, 42 (3), pp.261-269. hal-02694822

\section{HAL Id: hal-02694822 \\ https://hal.inrae.fr/hal-02694822}

Submitted on 1 Jun 2020

HAL is a multi-disciplinary open access archive for the deposit and dissemination of scientific research documents, whether they are published or not. The documents may come from teaching and research institutions in France or abroad, or from public or private research centers.
L'archive ouverte pluridisciplinaire HAL, est destinée au dépôt et à la diffusion de documents scientifiques de niveau recherche, publiés ou non, émanant des établissements d'enseignement et de recherche français ou étrangers, des laboratoires publics ou privés. 


\title{
Proteolysis of Type III Collagen by Collagenase and Cathepsin B Under High Hydrostatic Pressure
}

\author{
Eric Dufour, ${ }^{a}$ Michèle Dalgalarrondo, ${ }^{a}$ Guy Hervé, ${ }^{b}$ \\ René Goutefongea $^{a}$ \& Tomasz Haertlée ${ }^{a *}$
}

${ }^{a}$ L.E.I.M.A. - Institut National de la Recherche Agronomique BP 1627, 44316, Nantes Cedex 03, France

${ }^{b}$ URA-C.N.R.S. 554, Université P and M Curie, 96 Boulevard Raspail 75006, Paris, France

(Received 25 August 1995)

\begin{abstract}
The effects of high hydrostatic pressures on the kinetics of hydrolysis of type III collagen from calf skin by collagenase and cathepsin $B$ were studied. Collagen hydrolysates sampled at different time intervals $(0-90 \mathrm{~min})$ and at different pressures $(0.1-300 \mathrm{MPa})$ were analysed by reverse-phase high pressure liquid chromatography. The rate of collagen hydrolysis decreased up to $300 \mathrm{MPa}$ for both enzymes. The rate of collagen hydrolysis with cathepsin $B$ was drastically reduced between 0.1 and $100 \mathrm{MPa}$. Significant differences in the populations of the peptides in cathepsin $B$ hydrolysates were observed in chromatograms corresponding to different pressures. This indicated that some amino acid side-chains were less exposed to cathepsin $B$ recognition on the surface of collagen molecules at high pressures. In contrast, the chromatograms of collagenase hydrolysates showed similar patterns, varying only by the peak heights in chromatograms corresponding to the 0.1-300 MPa pressure range. Pressureinduced decreases of the enzyme-apparent activities suggested that the activation volumes for the reaction of both enzymes were positive.
\end{abstract}

\section{INTRODUCTION}

Tropocollagen, the basic collagen structure, consists of three helical polypeptide chains intertwining to form a right-handed superhelix. Collagen fibrils (types I, II and III) are formed by interaction between the telopeptides of one collagen monomer and the triplehelical domain of one or more adjacent collagen monomers (Light \& Bailey, 1980). Telopeptides are small non-triple-helical extension peptides at the $\mathrm{N}$ - and C-terminal ends of collagen $\alpha$-chains (Otter et al., 1993). Collagen is the protein conferring resistance to mechanical stress on bones, cartilages, tendons and muscle connective tissues. It is predominantly responsible for the toughness of meat from aged animals, probably the most critical quality trait for the consumer. The meat quality of muscles with a high

*Author to whom correspondence should be addressed. 
connective tissue content is, and could be still further, improved by specific proteolysis by endogenous or added proteases.

Collagenases are by definition the only proteases to efficiently digest the native collagen under physiological conditions. Bacterial collagenases generally cleave the triple-helical collagen at the X-Gly bond in X-Gly-Pro-Y sequences (Nagai, 1961; Steinbrink et al., 1985). Although the triple-helical collagen molecule is extremely resistant to degradation by non-specific proteases, cathepsins B and L (Burleigh et al., 1974; Kirschke et al., 1982; Maciewicz \& Etherington, 1988; Beltran et al., 1992) have been shown to cleave native collagen, inducing the depolymerization of cross-linked fibres. Although the cleavage sites of cathepsins on collagen molecules have not yet been fully characterized, it has been suggested that these proteases act primarily on the telopeptides (Kirschke et al., 1982). Based on differential scanning calorimetry studies, Beltran et al. (1992) suggested, however, that cathepsin B and bacterial collagenase may have similar mechanisms of action on insoluble collagen.

High hydrostatic pressures perturb protein structure (e.g., folding, specific volume, flexibility) and enzyme activity. In contrast to fibrous proteins, the interior of globular proteins is highly compressible (Gekko \& Hasegawa, 1986). The thermal stability of collagen (Gekko \& Koga, 1983) and gelatin gels (Gekko \& Fukamizu, 1991) is enhanced under high pressure. These results indicate that the volume change following the helix to coil transition of collagen is positive in water. Protein-water interactions play an important role in the stability of collagen structure (Gekko \& Koga, 1983). Most globular proteins are denatured in the $400-600 \mathrm{MPa}$ pressure range and these conformational changes increase the solvent-accessible surface area, i.e., hydration of proteins (Heremans, 1982). The activity of several proteinases such as thermolysin (Fukuda \& Kunugi, 1984), trypsin (Groß et al., 1993) and cathepsin B (Kurth, 1986) is enhanced by moderate hydrostatic pressure (below $200 \mathrm{MPa}$ ). The rate of gelatin hydrolysis with pepsin is, however, decreased by high pressures (Laidler, 1951). In general, catalytic rate constants of enzymatic (and non-enzymatic) reactions are modified by high pressures. Pressure modifies both kinetic constants (depending on the catalyzed reaction), and protein structure - what is produced by pressure induced conformation changes of substrate and/or enzyme as, for example, altered enzyme flexibility (Groß et al., 1993). High pressures in the $100-300 \mathrm{MPa}$ range might be a way to increase proteolytic activities in meat and, as a consequence, the quality of aged meat (Homma et al., 1994).

In the present study, we have examined the influence of pressures in the range $0.1-$ $300 \mathrm{MPa}$ on collagenase and cathepsin B hydrolysis of type III collagen. Aliquots withdrawn at various time intervals have been analysed by reverse-phase HPLC. Pressuredependent kinetics of the hydrolysis of type III collagen by collagenase and cathepsin B are reported.

\section{MATERIALS AND METHODS}

Trifluoroacetic acid (TFA) was obtained from Pierce Chemicals (Rockford, IL, USA). Collagen (type III, acid soluble, from calf skin), cathepsin B (from bovine spleen) and collagenase (type F from Clostridium histoliticum) were from Sigma (St Quentin Fallavier, France) and were used without further purification. All other reagents were of analytical grade. Collagen stock solution $(2 \mathrm{mg} / \mathrm{ml})$ was prepared in $10 \mathrm{mM} \mathrm{HCl}$.

The HPLC equipment consisted of an auto-sampling injector (Gilson model 231), assisted by a chromatography work station (Maxima 820 , Waters), two solvent delivery systems (Waters model 510), a temperature control system and a variable wavelength U.V. monitor (Waters model 455). 


\section{High pressure apparatus}

The pressure bomb described by Hui Bon Hoa et al. (1990) was used in this study. It allows intermittent sampling without release of pressure in the reaction chamber. Its maximum operating pressure is $400 \mathrm{MPa}$ and the dead time of sampling is $10-15 \mathrm{~s}$. The reaction medium (volume $=17 \mathrm{ml}$ ) was stirred and thermostated in the high pressure chamber.

\section{Hydrolysis of collagen by collagenase and cathepsin B}

\section{Collagenase hydrolysis}

The collagen stock solution was diluted to $1 \mathrm{mg} / \mathrm{ml}$ with $0.2 \mathrm{M}$ Tris buffer $\mathrm{pH} 7.5$ containing $20 \mathrm{mM} \mathrm{CaCl}_{2}$. Collagenase $(0.5 \mathrm{mg} / \mathrm{ml})$ was dissolved in $0.1 \mathrm{M}$ Tris buffer, $10 \mathrm{mM}$ $\mathrm{CaCl}_{2}, \mathrm{pH} 7.5$ and added to the incubation medium at an $\mathrm{E} / \mathrm{S}$ ratio (enzyme/substrate ratio) of $0.5 \%(\mathrm{w} / \mathrm{w})$. The reaction mixture was incubated at $27^{\circ} \mathrm{C}$ at pressures ranging between 0.1 and $300 \mathrm{MPa}$. Aliquots $(0.8 \mathrm{ml})$ were withdrawn at intervals of $0,20,40,60$ and $90 \mathrm{~min}$. The reaction was stopped by the addition of $80 \mu \mathrm{l}$ of $2 \mathrm{M} \mathrm{HCl}$.

\section{Cathepsin $B$ hydrolysis}

The collagen stock solution was diluted to $1 \mathrm{mg} / \mathrm{ml}$ by adding $0.1 \mathrm{M}$ Tris/acetate buffer, $4 \mathrm{mM}$ EDTA, $10 \mathrm{mM}$ DTT, $\mathrm{pH}$ 6.5. Cathepsin B $(1 \mathrm{mg} / \mathrm{ml})$ was dissolved in $50 \mathrm{mM}$ Tris/ acetate buffer, $2 \mathrm{mM}$ EDTA, $\mathrm{pH} 6.5$ and added to the reaction mixture at an E/S ratio of $1.3 \%(\mathrm{w} / \mathrm{w})$. During incubation at $35^{\circ} \mathrm{C}$ at different pressures $(0.1,100,200$ and $300 \mathrm{MPa})$, aliquots $(0.8 \mathrm{ml})$ were withdrawn at intervals of $0,20,40,60$ and $90 \mathrm{~min}$. The reaction was stopped by the addition of $0.2 \mathrm{M}$ iodoacetic acid $(0.8 \mathrm{ml})$.

All the $\mathrm{pH}$ values reported are those measured at $0.1 \mathrm{MPa}$. As described previously, the $\mathrm{pH}$ of Tris buffer increases by 0.02 units per $100 \mathrm{MPa}$ (Neuman et al., 1973).

\section{HPLC analysis of collagen hydrolysates}

Collagen hydrolysates were analysed by reversed phase HPLC using a Nucleosil C18 column ( $4.6 \mathrm{~mm}$ diameter $\times 25 \mathrm{~cm}, \mathrm{SFCC}$, Gagny, France). The column was equilibrated with $100 \%$ solvent $\mathrm{A}\left(0.11 \%\right.$ TFA in $\left.\mathrm{H}_{2} \mathrm{O}\right)$. In the case of collagenase hydrolysates, elution was performed with a linear gradient from 0 to $60 \%$ solvent $\mathrm{B}\left(\mathrm{H}_{2} \mathrm{O} 40 \%, \mathrm{CH}_{3} \mathrm{CN}\right.$ $60 \%, 0.09 \%$ TFA) in $39 \mathrm{~min}$. In the case of cathepsin B hydrolysates, isocratic elution in $100 \%$ solvent A was performed during the first $15 \mathrm{~min}$ to remove salts, then elution was continued with a linear gradient to $60 \%$ solvent B in $39 \mathrm{~min}$. In both cases, the temperature of column was maintained at $30^{\circ} \mathrm{C}$ and absorbance was measured at $214 \mathrm{~nm}$. The data were acquired on a NEC APC-IV microcomputer.

For all chromatograms, collagen and peptide yields were determined by peak integration using Maxima 820 software (Waters).

\section{RESULTS}

The disappearance of type III collagen hydrolysed with collagenase and cathepsin $B$ at various pressures is shown in Fig. $1 \mathrm{~A}$ and $\mathrm{B}$, respectively. The area of the two collagen peaks (see Discussion and Fig. 2A) was used to measure the disappearance of collagen by proteolysis. The rate of collagen hydrolysis decreased with increasing pressure up to $300 \mathrm{MPa}$ for both enzymes. However, the trends are different for the two enzymes. It was 


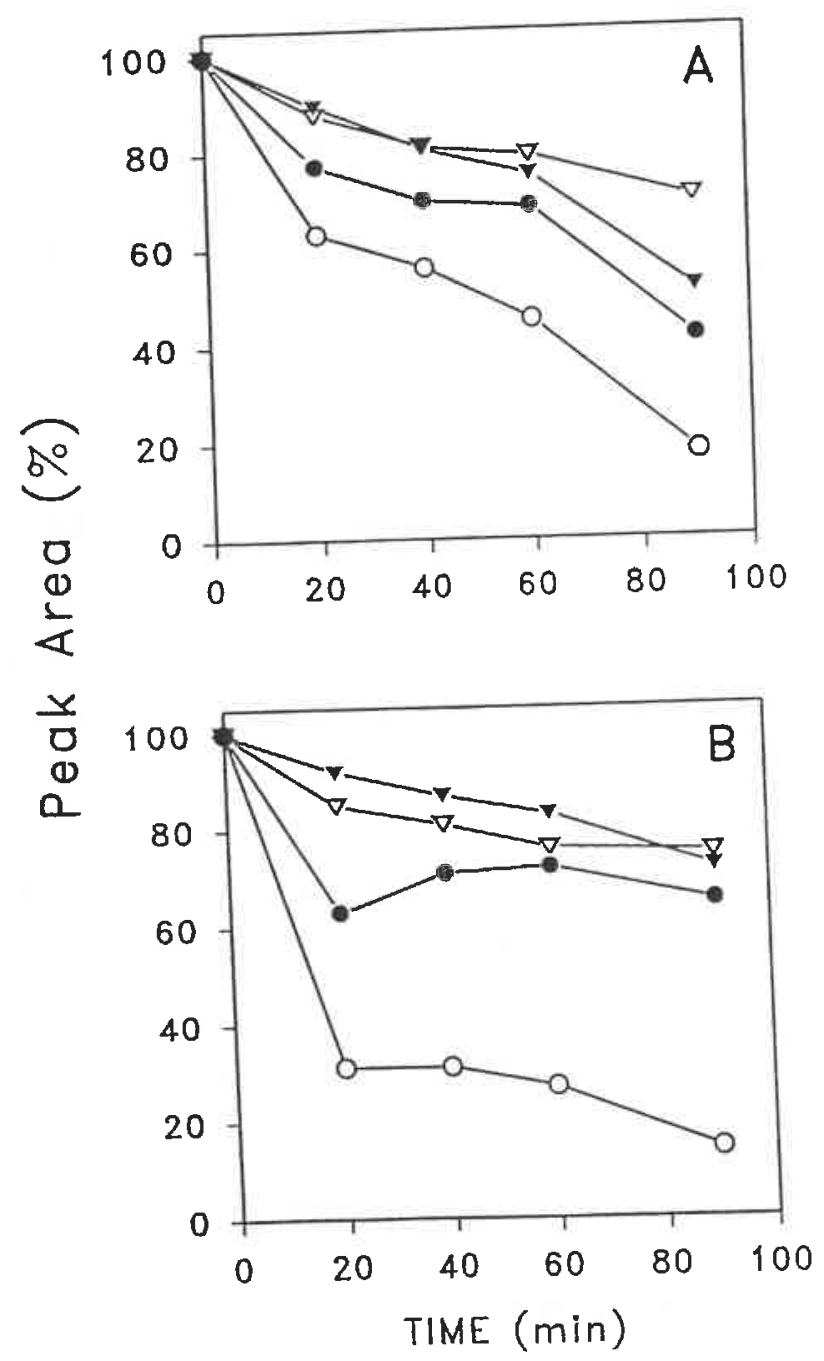

Fig. 1. Disappearance over time of collagen (expressed as its normalized HPLC peak area) after hydrolysis by collagenase (A) and cathepsin $\mathrm{B}(\mathrm{B})$ as a function of pressure. $(\mathrm{O})$ : $0.1 \mathrm{MPa}$; (ब): $100 \mathrm{MPa} ;(\nabla): 200 \mathrm{MPa} ;(\nabla): 300 \mathrm{MPa}$.

observed that the rate of collagen hydrolysis with collagenase decreased linearly in the $0.1-200 \mathrm{MPa}$ pressure range. In contrast, collagen hydrolysis with cathepsin B showed the greatest reduction between 0.1 and $100 \mathrm{MPa}$. After $90 \mathrm{~min}, 85,35$ and $25 \%$ of the collagen had been hydrolysed at $0.1,100$ and $200 \mathrm{MPa}$, respectively.

Figure 2 shows the chromatographic profiles of collagen and collagen hydrolysates obtained with collagenase at $0.1,100$ and $200 \mathrm{MPa}$ after a $60 \mathrm{~min}$ incubation. Collagen was eluted as two peaks (retention times $=33.0$ and $35.3 \mathrm{~min}$ ) under the conditions used (Fig. 2A). The chromatograms of the collagenase hydrolysates in the $100-300 \mathrm{MPa}$ pressure range resemble one another, with some variation in peak heights (Fig. 3). The yield of peak at 10.18 min was decreased significantly only at $300 \mathrm{MPa}$; but the amounts of peaks at $22.3 \mathrm{~min}$ and $27.2 \mathrm{~min}$ were reduced drastically at high pressure (Fig. 3). Due to the occurrence of glycine and proline residues in the $\alpha 1$-chains, collagen has a very large number of potential cleavage sites for collagenase. It appears that most of them remain capable of being hydrolysed by collagenase under high pressure, but the rate of release is decreased. In contrast with collagenase, cathepsin B hydrolysates of collagen showed different chromatographic profiles as a function of pressure (Fig. 4). As shown in 
Fig. 4A, peaks corresponding to dithiothreitol derivatives were eluted at 25.5 and 30.2 min. At atmospheric pressure, most of the initial collagen disappeared after 90 min. Numerous products of collagen hydrolysis were eluted between 35 and 46 min with the highest peak at $45.6 \mathrm{~min}$. However, at higher pressures, the peptides eluted between 35

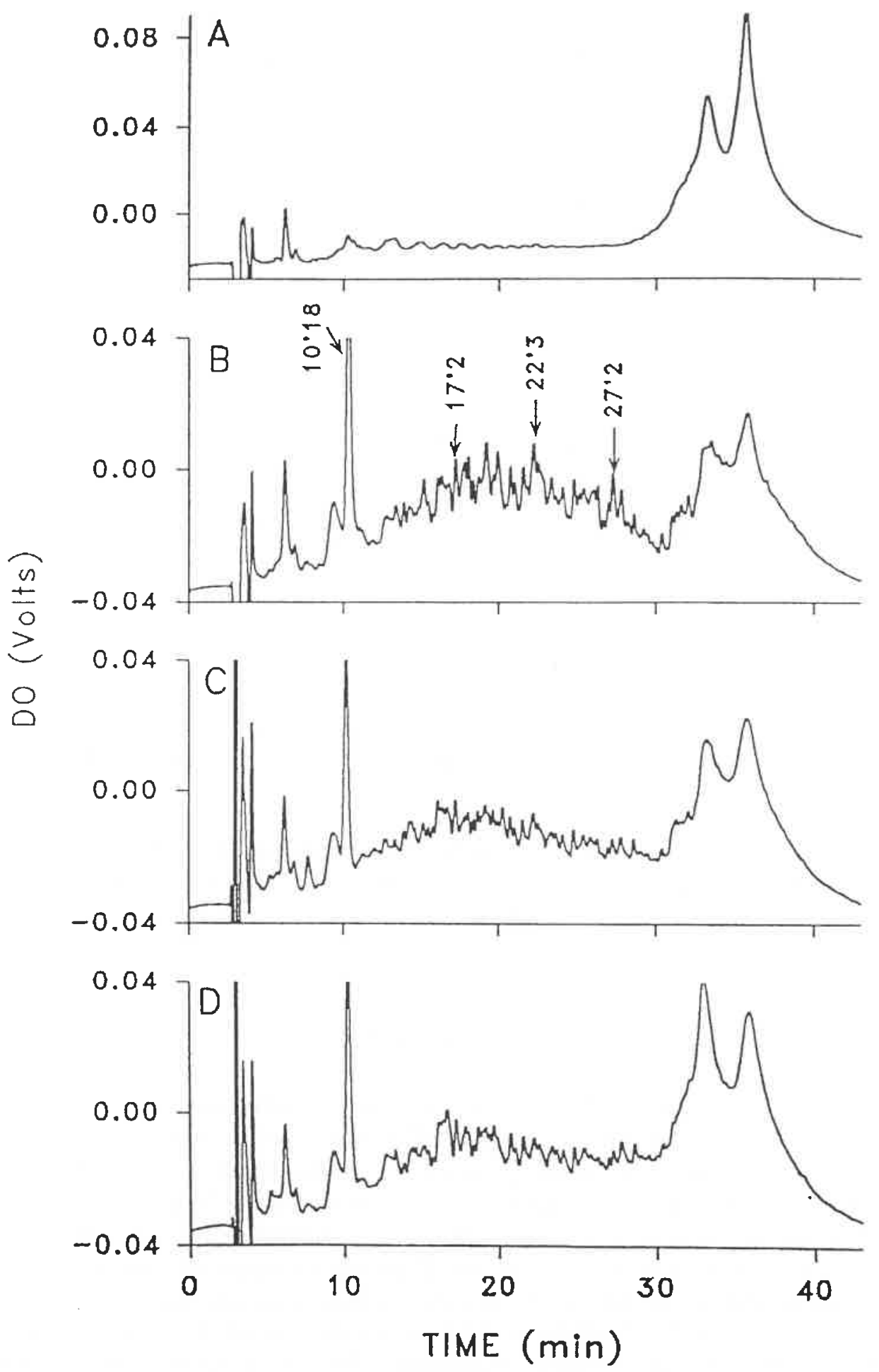

Fig. 2. Reverse-phase HPLC analysis of collagen hydrolysates obtained after 60 min hydrolysis by collagenase at different pressures. (A) collagen; (B) $0.1 \mathrm{MPa}$; (C) $100 \mathrm{MPa}$; (D) $200 \mathrm{MPa}$. Chromatography conditions are as described in Materials and Methods. 

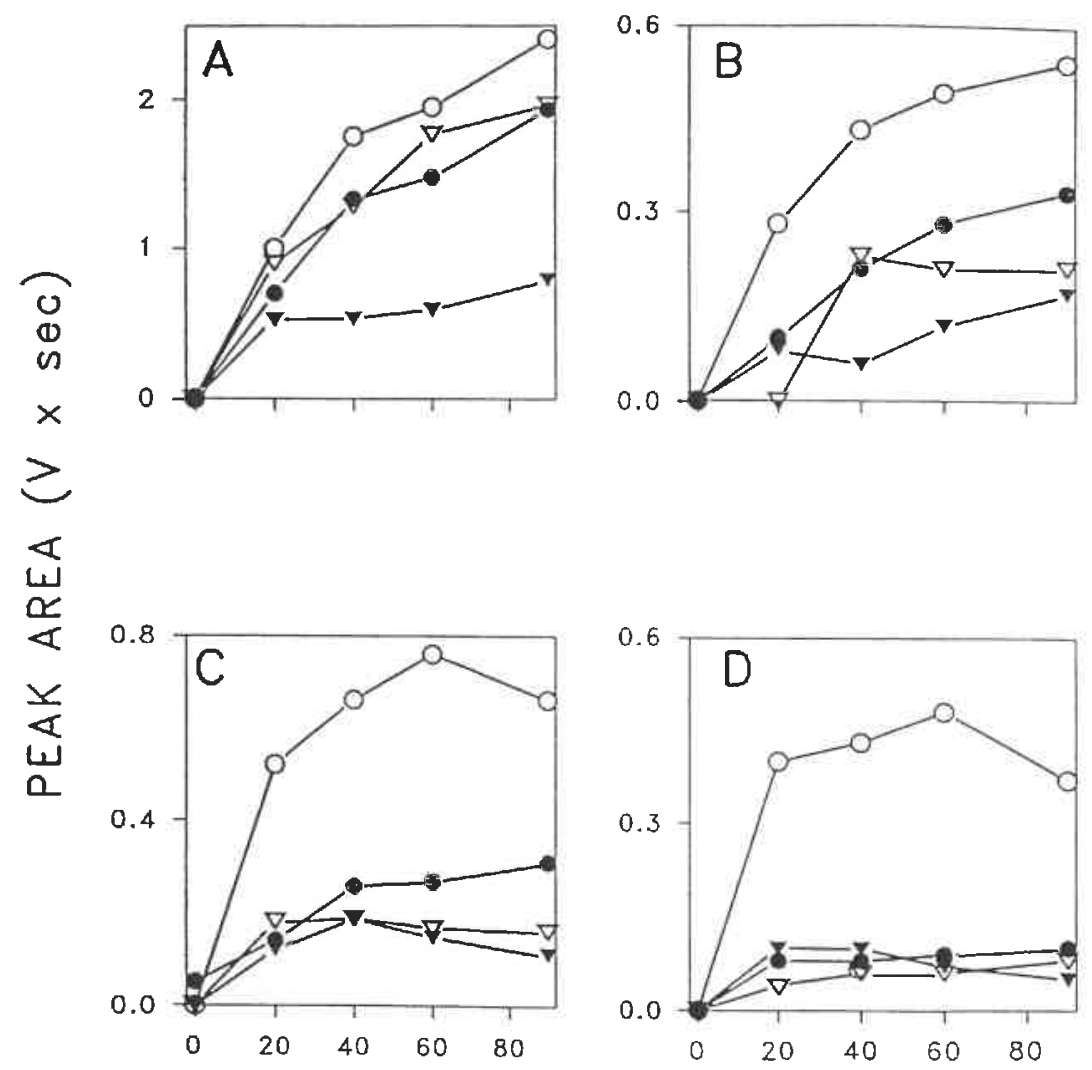

TIME (min)

Fig. 3. Time course of the evolution of four peptides as a function of pressure: (A) peak at 10.18 min; (B) peak at $17.20 \mathrm{~min}$; (C) peak at $22.30 \mathrm{~min}$; and (D) peak at $27.2 \mathrm{~min}$. For peptide numbering see Fig. 2. Pressures are: $(\mathrm{O}): 0.1 \mathrm{MPa}(\boldsymbol{\odot}): 100 \mathrm{MPa} ;(\nabla): 200 \mathrm{MPa} ;(\nabla): 300 \mathrm{MPa}$.

and $43 \mathrm{~min}$ were not observed, even after $90 \mathrm{~min}$ incubation (Fig. 4C and D). After $90 \mathrm{~min}$, only the peak at $45.6 \mathrm{~min}$ was still observed. This suggests that in the tropocollagen molecule, only a few proteolytic sites are accessible to cathepsin $B$ under high pressure.

\section{DISCUSSION}

As reported by Stoltz et al. (1972), the observed heterogeneity of the collagen used (Fig. 2A) could result from the hydrolysis of a small portion of the telopeptide during purification. Previous studies (Burleigh et al., 1974; Kirschke et al., 1982; Maciewicz \& Etherington, 1988; Beltran et al., 1992) have shown that cathepsins B and L hydrolyse collagen in solution, as well as collagen fibrils and insoluble collagen. The $\beta$-components of collagen fibrils are degraded by cathepsin B giving $\alpha$-chains (Burleigh et al., 1974). This has been interpreted as an attack on the non-helical peptide regions eliminating crosslinkages. The major peak observed at $45.6 \mathrm{~min}$ (and eluted just before collagen) could result from the removal of collagen telopeptides by cathepsin $B$. This suggests that the enzyme is almost unable to attack the collagen triple helix.

The patterns of collagenase hydrolysates obtained at $0.1 \mathrm{MPa}$ are different from the patterns seen with cathepsin B. No high molecular weight component is left after 


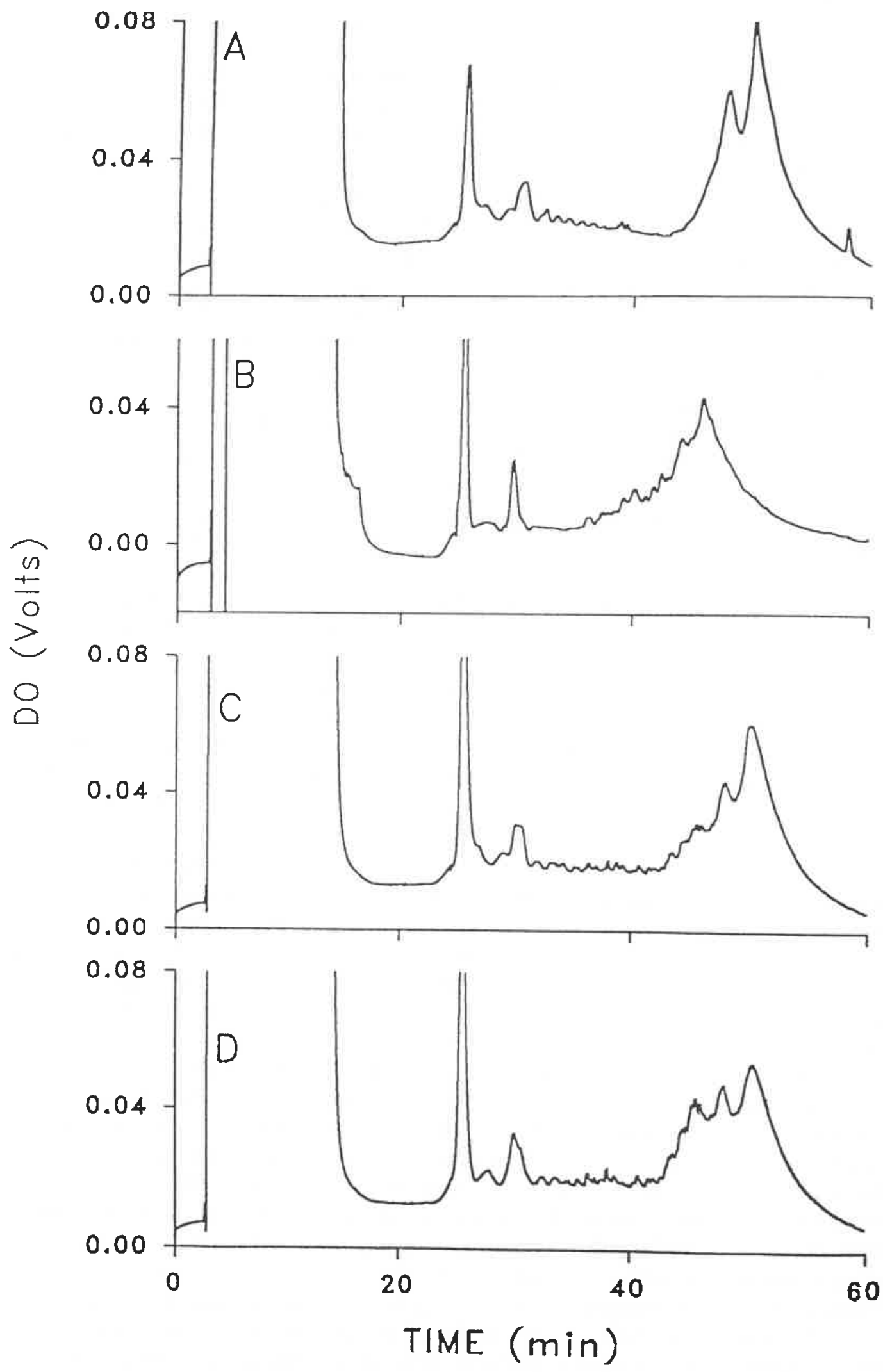

Fig. 4. Reverse-phase HPLC analysis of collagen hydrolysates obtained after 90 min hydrolysis by cathepsin B at different pressures. (A) collagen + DTT; (B) $0.1 \mathrm{MPa}$; (C) $100 \mathrm{MPa}$; (D) $200 \mathrm{MPa}$. Chromatography conditions are as described in Materials and Methods. 
hydrolysis with collagenase. The collagen $\alpha$ l-chain is rapidly degraded by collagenase to lower molecular weight peptides than the peak with 45.6 min retention time (cathepsin B hydrolysates; Fig. 4). These observations imply that cathepsin B and collagenase have different mechanisms of collagen breakdown. Cathepsins are able to degrade collagens within their non-helical domains (Evans \& Etherington, 1978; Maciewicz et al., 1990). Collagenases are the only proteases to be able to cleave the triple helical collagen.

This work was designed to address two questions: could high pressure increase the rate of collagen proteolysis? What are the effects of high pressure induced conformational changes and stability of collagen structure on the outcome of proteolysis?

The results indicate that the rates of collagen hydrolysis decrease with increasing pressure. It is well known that high pressures induce conformational changes on both substrates and enzymes. Pressure also modifies the flexibility of enzymes. Globular proteins (e.g., enzymes) exhibiting a positive compressibility are more subject to a decrease of their flexibility than fibrous proteins (Gekko \& Hasegawa, 1986). As suggested by Groß et al. (1993), pressure induced reduction in partial specific volume may reduce flexibility and hence inhibit enzymatic activity. However, the (apparent) activity of cathepsin B is increased by high pressure (up to $150 \mathrm{MPa}$ ) using synthetic substrates (Kurth, 1986) suggesting that the enzyme is not inhibited by high pressures. Despite that to our knowledge there are no kinetic data for collagenase under high pressure, pressure-dependent increasing activity has been reported for thermolysin (Fukuda \& Kunugi, 1984; Groß et al., 1993), a zinc protease like collagenase. In addition, it has been shown that the rates of $\beta$-lactoglobulin hydrolysis by thermolysin (Dufour et al., 1992) and pepsin (Dufour et al., 1995) increase with pressure up to $200 \mathrm{MPa}$. In contrast, Laidler (1951) has reported that the rate of gelatin hydrolysis by pepsin decreases with increasing pressure.

Globular and fibrous proteins display different compressibilities under high pressure. The partial specific adiabatic compressibility of gelatin, but not of globular proteins, is negative due to the predominance of hydration effects (Gekko \& Hasegawa, 1986). Furthermore, the enhanced stability of collagen under high pressure indicates that the volume change following the helix to coil transition of the protein is positive in water (Gekko \& Koga, 1983).

It is known that pressure modifies also the kinetic constants of chemical reactions. The logarithm of the rate of reaction changes linearly with pressure and the slope of the line corresponds to the activation volume (Groß et al., 1993). Decreasing activity with increasing pressure implies a positive volume of activation, and vice versa. Activation volumes measured for thermolysin using dipeptides as substrates are negative (Fukuda \& Kunugi, 1984; Groß et al., 1993). Similarly, the enhanced activity of cathepsin B toward $N$-benzoyl-(D,L)-arginine-2 naphtylamide substrate under high pressure (Kurth, 1986) implies a negative volume of activation. In the case studied of collagen proteolysis, it is impossible to evaluate activation volume since many peptides' bonds are cleaved. The effect of pressure on the kinetics of each cleavage site cannot be distinguished, but the volume change of the reaction can be calculated according to Laidler (1951). Assuming that the state in question is that of an ideal gas, the slope of the logarithmic plot of hydrolysis rate vs pressure allows derivation of the volume change of the reaction. Studies of $\beta$-lactoglobulin hydrolysis by thermolysin under high pressure also indicate that the activation volume is negative (Dufour et al., 1992). In contrast, the apparent activities of cathepsin B and collagenase, using collagen as substrate are decreased under high pressure. Our results, as well as the study of gelatin hydrolysis by pepsin under high pressure (Laidler, 1951), reveal a positive activation volume for these reactions. Considering this thermodynamic property of collagen, and of fibrillar proteins in general, under high pressure, it may seem unlikely that high pressure could be used to increase specific proteolysis of collagen in meat. This speculation is in good agreement with the 
results obtained by Suzuki et al. (1993). In their report, no significant differences in the ultrastructure, electrophoretic pattern, thermal solubility and thermogram of differential scanning calorimetric analysis of the intramuscular collagen were observed among the pressurized and untreated muscles. Nevertheless, high pressure is a valuable tool used to perturb the structure of proteins and to modify the outcome of globular protein hydrolysis with various proteases (Dufour et al., 1995; Homma et al., 1994).

\section{ACKNOWLEDGEMENTS}

This work was supported by the Ministère de la Recherche et de la Technologie (M.R.T. 91 G 0574).

\section{REFERENCES}

Beltran, J. A., Bonnet, M. \& Ouali, A. (1992). Meat Sci., 32, 299.

Burleigh, M. C., Barett, A. J. \& Lazarus, G.S. (1974). Biochem. J., 137, 387.

Dufour, E., Hervé, G. \& Haertlé, T. (1992). In High Pressure and Biotechnology, eds C. Balny, R. Hayashi, K. Heremans \& P. Masson. John Libbey Inc./INSERM, Paris, pp. 147.

Dufour, E., Hervé, G. \& Haertlé, T. (1995). Biopolymers, 35, 475.

Evans, P. \& Etherington, D. J. (1978). Eur. J. Biochem., 83, 87.

Fukuda, M. \& Kunugi, S. (1984). Eur. J. Biochem., 142, 565.

Gekko, K. \& Fukamizu, M. (1991). Int. J. Biol. Macromol., 13, 295.

Gekko, K. \& Hasegawa, Y. (1986). Biochemistry, 25, 6563.

Gekko, K. \& Koga, S. (1983). Agric. Biol. Chem., 47, 1027.

Groß, M., Auerbach, G. \& Jaenicke, R. (1993). FEBS Lett., 321, 256.

Heremans, K. (1982). Ann. Rev. Biophys. Bioeng., 11, 1.

Homma, N., Ikeuchi, Y. \& Suzuki, A. (1994). Meat Sci., 38, 219.

Hui Bon Hoa, G., Hamel, G., Else, A., Weill, G. \& Hervé, G. (1990). Analyt. Biochem., 187, 258.

Kirschke, H., Kembhavi, A. A., Bohley, P. \& Barrett, A. J. (1982). Biochem. J., 201, 367.

Kurth, B. K. (1986). J. Food Sci., 51, 663, 667.

Laidler, K. J. (1951). Arch. Biochem., 30, 226.

Light, N. D. \& Bailey, A. J. (1980). In Biology of Collagen, eds A. Viidik \& J. Vuust. Academic Press, New York, pp. 15.

Maciewicz, R. A. \& Etherington, D. J. (1988). Biochem. J., 256, 433.

Maciewicz, R. A., Wotton, S. F., Etherington, D. J. \& Duance, V. C. (1990). FEBS Lett., 269, 189.

Nagai, Y. (1961). J. Biochem., 50, 486.

Neuman, R. C., Kauzman, W. \& Zipp, A. (1973). J. Phys. Chem., 77, 2687.

Otter, A., Scott, P. G. \& Kotovych, G. (1993). Biopolymers, 33, 1443.

Steinbrink, D. R., Bond, M. D. \& Van Wart, H. E. (1985). J. Biol. Chem., 260, 2771.

Stoltz, M., Timpl, R. \& Kuhn, K. (1972). FEBS Lett., 26, 61.

Suzuki, A., Watanabe, M., Ikeuchi, Y., Saito, M. \& Takahashi, K. (1993). Meat Sci., 35, 17. 
